BENTUK PERTUNJUKAN GURITAN PADA TRADISI PERNIKAHAN DI KOTA PAGARALAM

DedyFirduansyah, AbiKaroma Batubara

EKSISTENSI MUSIK KOLINTANG KAYU DALAM KEHIDUPAN PIKPP DI PT.PURSI PALEMBANG SUMATERA SELATAN

RIO EKA PUTRA

ESTETIKA TARI MELAJU DENGAN MUTU

Rully Rochayati, Treny Hera

KAJIAN SOSIOLOGI TARI KEBAGH DI MASYARAKAT DESA PENGANDONANKOTA PAGAR ALAMRANI CHINTIA SARI

KONTRIBUSI GURU SENI BUDAYA DALAM PENGEMBANGAN KREATIFITAS SISWA PADA PEMBELAJARAN SENI TARI

Naomi Diah Budi Setyaningrum

45

PENERAPAN METODE RESITASI DALAM PEMBELAJARAN NOTASI TARI PADA PROGRAM STUDI PENDIDIKAN SENDRATASIK UNIVERSITAS PGRI PALEMBANG

EfitaElvandari

PENGARUH METODE KERJA KELOMPOK PADA HASIL PEMBELAJARAN TARI TOPENG IRENG DI KELAS VIII SMP NEGERI 15 PALEMBANG

NEMI KAROLINA

PENGARUH MUSIK DANGDUTTERHADAP KECERDASAN EMOSI REMAJA SMPKELAS IX

NOVDALY FILLAMENTA

SITI RAFIAH SEBAGAI TOKOH PEREMPUAN PENGEMBAN PERISTIWA DALAM SYAIR ABDUL MULUK KARYA RAJA ALI HAJI

MOHAMMAD ARFANI

STRUKTUR KERUANGAN TARI REJANG RENTENG DALAM UPACARA PERSEMBAHYANGAN DI PURA PUSEH DESA KALIREJO KECAMATAN BELITANG II KABUPATEN OKU TIMUR

IWAYAN AYUNITA 


\title{
ESTETIKA TARI MELAJU DENGAN MUTU
}

\author{
Oleh:

\section{Rully Rochayati} \\ Treny Hera \\ (Dosen FKIP Universitas PGRI Palembang)
}

\begin{abstract}
ABSTRAK
Tari Melaju Dengan Mutu merupakan tari kreasi baru yang diciptakan berlandaskan inovasi motto Universitas PGRI Palembang yaitu "Melaju Dengan Mutu" yang memiliki arti perkembangan Universitas dalam segala bidang akan selalu ditingkatkan dengan capaian waktu dan bermutu dalam bidang pendidikan. Penelitian ini bertujuan untuk mendeskripsikan Estetika tarinya yang dapat dilihat melalui bentuk tari dalam konteks penampilannya dari komponen non verbal. Hasil penelitian dengan metode peneitian deskripstif kualitati dengan cara pengumpulan data lewat observasi, wawancara, dan dokumentasi menunjukan nilai estetika tari Melaju Dengan Mutu dapat dilihat dari bentuk, isi, dan penampilan dari pertunjukan tari Melaju Dengan Mutu yang sementara waktu dikhususkan dipertunjukan untuk acara wisuda saja. Isi pertunjukan nampak pada gagasan, suasana, dan pesan yang ada dalam pertunjukan tari Melaju Dengan Mutu yang mengandung nilai-nilai Prinsip etika yang berlaku pada masyarakat dalam hal ini civitas akademik lingkup Universitas PGRI Palembang menjadi bahan pertimbangan dalam pembuatan sebuah karya tari.
\end{abstract}

Kata Kunci: Estetika Tari

\section{A. PENDAHULUAN}

Penciptaan karya tari harus diciptakan dan dirancang secara kreatif berlandaskan estetika sebagai unsur penciptaan.Secara prosedural ,proses penciptaan karya tari dapat dilakukan atas dasar motivasi koreografer.Proses penciptaan tarian adalah proses kreasi. Proses ini akan terjadi dari beberapa langkah yaitu menetapkan tujuan penciptaan tari. Hal ini berkaitan dengan fungsi tarian yang akan dibuat.untuk keperluan apakah tarian itu diciptakan. Apakah untuk upacara, untuk tujuan estetika belaka, ataukah untuk tujuan lainnya.

Dalam sebuah penciptaan bentuk tari, tema merupakan bagian yang sangat
penting.Tema yang dapat diambil dari berbagai konteks.Tema yang dimaksud disini adalah gagasan atau sumber tarian yang dikembangkan.Tema tersebut dapat diambil dari kehidupan kita sehari-hari.Dari cerita-cerita yang sudah berkembang di masyarakat, ataukah dari hasil penciptaan sendiri secara abstrak. Mengembangkan tema menjadi subsub tema kemudian diterjemahkan kedalam rangkaian gerak-gerak maknawi .Rangkaian gerak maknawi ini kemudian digabungkan dengan gerak-gerak murni yang telah baku dan tersedia.

Tari Melaju Dengan Mutu merupakan tari kreasi baru yang diciptakan berlandaskan inovasi motto Universitas PGRI Palembang yaitu "Melaju Dengan Mutu" yang memiliki arti 
perkembangan Universitas dalam segala bidang akan selalu ditingkatkan dengan capaian waktu dan bermutu dalam bidang pendidikan.

Kata Estetika berasal dari kata Yunani aesthesis yang berarti perasaan, selera perasaan atau taste.Estetika adalah salah satu cabang filsafat. Secara sederhana, estetika adalah ilmu yang membahas keindahan, bagaimana ia bisa terbentuk, dan bagaimana seseorang bisa merasakannya.Suatu karya seni bukan hanya memberikan pengetahuan dan pengalaman yang berharga bagi kehidupan saja, karena juga memiliki nilai keindahan.Pengertian keindahan membawa kita pada pertanyaan, apakah sifat dasar keindahan itu ada pada karya yang indah atau hanya tanggapan perasaan saja terhadap karya tersebut?Dari persoalan ini melahirkan dua teori yang bertentangan, yaitu teori estetika.

\section{Teori subjektif Teori yang} menyatakan bahwa adanya nilai keindahan hanya tanggapan perasaan orang yang melihat karya tersebut.Teori ini hanya berdasarkan naluri saja untuk menyatakan indah tanpa penjelasan tentang ciri-cirikeindahan dari benda yang dilihatnya.Teori obyektif ialah Teori yang menyatakan bahwa nilai keindahan ada pada karya yang dilihatnya.Teori ini melihat nilai keindahan dari komposisi dan unsur-unsur pembentuk karya yang dilihatnya, sehingga kita bisa memberikanpenjelasan tentang ciri-ciri keindahan yang terkandung pada suatu karya seni.Kedua teori diatas pada dasarnya adalah benar, masing-masing memiliki kelebihan dan kekurangan.Tetapi para ahli di abad modern ini lebih cenderung pada teori objektif.Dengan demikian untuk menanggapi karya seni yang bermutu, terlebih dahulu perlu kita ketahui prinsip-prinsip seni meliputi komposisi dan unsur-unsur seni.

Djelantik mendefinisukan bahwa yang dinamakan estetika adalah suatu ilmu yang mempelajari segala sesuatu yang berkaitan dengan keindahan, mempelajari semua aspek dari apa yang kita sebut keindahan .Dalam penjelasanya estetika adalah filsafat seni yang berisi segala macam pemikiran dan pembahasan mendalam (filosofis) tentang seni dan keindahan.

Beberapa pengertian yang telah dijelaskan di atas menunjukkan dengan jelas bahwa yang dinamakan estetika atau yang biasa disebut dengan ruang lingkup bahasan estetika adalah meliputi dua pokok bahasan utama, yaitu segala persoalan yang berkaitan dengan keindahan atau yang biasa orang orang sebut estetis dan persoalan yang berkaitan dengan seni.Kadangkala pembahasan kedua persoalan itu saling terkait dan sulit dipisahkan.

Suatu tari bisa tercipta seiring dengan naskah tari yang disusun sebagai pedoman tertulis seorang koreografer.Motivasi koreografer untuk menciptakan tari Melaju Dengan Mutu sebagai tari kreasi milik FKIP Universitas PGRI Palembang yang berfungsi 
sebagai tari hiburan dan tontonan.Penelitian Estetika tari Melaju Dengan Mutu perlu dilakukan agar Estetika tari tersebut terdokumentasi secara ilmiah sehingga bahan hasil penelitian dapat dibaca oleh masyarakat sebagai bahan pengetahuan tari kreasi baru.

$$
\text { Berdasarkan latar belakang }
$$
permasalahan yang telah diuraikan, maka perumusan masalah penelitian ini adalah bagaimana Estetika tari Melaju Dengan Mutu?.Hasil penelitian Estetika Tari Melaju Dengan Mutu bermanfaat sebagai bahan dokumentasi juga memberikan informasi bagi SDM di Lingkungan Universitas PGRI Palembang khususnya yang memiliki perhatian dengan keberadaaan seni tari sebagai identitas kampus yang memiliki budaya dan seni.

\section{B. METODE PENELITIAN}

\section{Variabel Penelitian}

Variabel penelitian adalah segala sesuatu yang akan menjadi objek pengamatan penelitian. Pemahaman yang bisa diambil berdasarkan definisi tersebut adalah bahwa dalam penelitian terdapat sesuatu yang menjadi sasaran, yaitu variabel, sehingga variabel ialah fenomena yang menjadi pusat perhatian penelitian untuk diobservasi atau diukur.Variabel dalam penelitian ini adalah variabel bebas atau variabel independen. Variabel ini disebut independen karena nilainya tidak bergantung pada dan tidak dipengaruhi oleh keadaan variabel lain dalam percobaan. Dalam penelitian ini variabelnya dalah estetika mengenai konsep keindahan tari buatan manusia.

\section{Subjek Penelitian}

Orang yang dijadikan sebagai sumber data atau sumber informasi oleh peneliti untuk riset Estetika tari Melaju Dengan Mutu adalah orang-orang terkait dengan proses penciptaan tari Melaju Dengan Mutu dan juga para pelaku dalam pertunjukannya. Beberapa informan yang dapat diperolrh data primer adalah SDM di lingkungan UPGRI Palembang dan juga penonton yang telah menyaksikan pertunjukan tari Melaju Dengan Mutu yang tentunya memiliki pengetahuan untuk menginterpersi estetika tari dengan bidang ilmu seni tari dan juga seni rupa untuk melihat keindahan berbusana dan konsep penataan busana juga riasnya.

\section{Metode Penelitian}

Metode dapat diartikan sebagai suatu cara untuk bergerak atau melakukan sesuatu secara sistematis dan tertata, keteraturan pemikiran dan tindakan, atau juga teknik dan susunan kerja dalam bidang atau lapangan tertentu. metode juga diartikan sebagai teknik dan peralatan khusus untuk menjelajah, memperoleh dan menganalisis informasi (Rohidi 2011:171) Penelitian ini bersifat deskriptif, tujuannya adalah menganalisis dan menyajikan data secara nyata sehingga mudah dipahami. Menurut Hamalik (2004:4) penelitian 
deskriptif adalah menganalisis dan menyajikan fakta secara sistematis sehingga dapat lebih mudah dipahami dan disimpulkan.Kesimpulan yang diberikan selalu jelas dasar faktanya, sehingga semuanya dapat dikembalikan langsung pada data yang diperoleh secara tidak terlalu dalam.

Metode penelitian penelitian Estetika Tari Melaju Dengan Mutu adalah metode penelitian kualitatif, dengan menggambarkan keadaan objek maupun subjek yang ada di lapangan secara nyata, mendeskrisikan atau memaparkan segala aktivitas penelitian yang dilakukan.Pendapat para ahli menyatakan bahwa metode penelitian kualitatif adalah metode yang digunakan untuk mendapatkan suatu data secara mendalam dan suatu data yang mengandung makna (Sugiyono 2015:1415).

\section{Instrumen Penelitian}

Alat bantu yang digunakan oleh peneliti untuk mengumpulkan data penelitian Estetika Tari Melaju Dengan Mutu yang paling utama adalah peneliti sendiri yang berpegangkan pada keilmuan tari dengan pedoman konsep estetika untuk memperoleh data Unsur unsur estetika A. Wujud atau rupa 1. Wujud yang mendasar 2.Susunan atau struktur B. Bobot atau isi 1.suasana 2. gagasan 3. pesan $\mathrm{C}$. Penampilan penyajian 1 . bakat 2 . keterampilan 3. sarana atau media dengan alat bantu berupa alat rekam untuk merekam video terutama sebagai wujud nyata ketika estetika suatu karya seni divisualkan melalui penyajiannya. Kemudian instrumen wawancara terkait dengan segala data yang ingin diperoleh sesuai dengan rumusan masalah.

\section{Prosedur Penelitian}

Prosedur penelitian merupakan langkah-langkah atau urutan-urutan yang harus dilalui atau dikerjakan dalam suatu penelitian. Tahapan awal adalah menentukan rumusan masalah penelitian, adapun penelitian Estetika Tari Melaju Dengan Mutu adalah memperdalam tentang rasa keindahan, menyempurnakan rasa keindahan objektif, menyempurnakan rasa keindahan subjektif, memupuk rasa kehalusan manusia, memperdalam pengertian keterkaitan wujud berkesenian dengan kehidupan, memantapkan kemampuan penilaian kaya seni. Setelah data terkumpul dengan berbagai metode dan juga konsep estetika sebagai kajian pustaka maka prosedur selanjutnya adalah mengolah data secara besar.

Prosedur dalam melakukan penelitian Estetika Tari Melaju Dengan Mutu diawali dengan cara Mengenali dan mendeskripsikan komponen-komponen bentuk komponen tari secara non verbal 2. Memahami hubungan antara komonen bentuk tari non verbal dengan estetika terhadap bentuk tari 3.Melakukan interprestasi berdasarkan konsep estetika. 4. Melakukan evaluasi berdasarkan: nilai-nilai yang berlaku di dalam konsep estetika dengan 
konteks pertunjukan sebuah bentuk tari yang telah dikemas dengan unsur-unsur keindahan.

\section{HASIL DAN PEMBAHASAN}

Penelitian ini dilakukan di Universitas PGRI Palembang. Universitas PGRI Palembang adalah salah satu universitas swasta di Kota Palembang yang berada di Jln. Jend A Yani Lorong Gotong Royong No. 9/10. 13 Uli.Seberang Ulu II Kota Palembang Sumatera Selatan 30116. Universitas ini memiliki 5 fakultas yaitu Fakultas Keguran dan Ilmu Pendidikan yang terdiri dari 12 program studi, fakultas Ekonomi terdiri dari 2 program studi, fakultas Teknik terdiri dari 3 program studi, fakultas Matematika dan IImu Pengetahuan Alam terdiri dari 2 program studi, fakultas Perikanan terdiri dari 2 program studi dan 1 program Pascasarjana dengan 3 program studi. Sedikit sejarah dari Universitas PGRI Palembang bermula berstatus sebagai STKIP PGRI yang kemudian diresmikan menjadi Universitas dengan SK Mendiknas No. 97/D/0/2000 tanggal 9 Juni 2000.

\section{Deskripsi Estetika Tari Melaju Dengan Mutu}

Estetika tari secara khusus hanya berkenaan dengan tari, namun lebih sering, dalam banyak kebudayaan, estetika tari itu tidak dapat dipisahkan dari teori seni secara umum, yang merupakan acuan yang dikenal luas dalam masyarakat yang bersangkutan.Dalam hal yang demikian, tari tak dapat dipahami dengan tepat apabila tidak dipahami juga prinsip-prinsip estetika yang mendasari musiknya, tata rupanya, bahkan prinsisp-prinsip etika yang berlaku dalam masyarakatnya, (Sedyawati, 2006: 299).Pembahasan tentang estetika tari berkaitan dengan teori tari secara umum yang melibatkan berbagai aspek dasar tari seperti ruang, waktu, tenaga.Selain itu konsep-konsep dasar perwujudan tari seperti tema, penari, pola lantai dan lain-lain. Pengetahuan dan pemahaman akan konsep dasar tari tersebut menjadi sangat penting karena dari konsep dasar tersebut maka akan terbentuk juga kesatuan dari bentuk tari itu sendiri. Prinsip estetika juga mengkait dengan prinsip-prinsip etika yang berlaku pada sebuah masyarakat. Proses ini pun tidak terjadi serta merta tetapi melalui berbagai pertimbangan-pertimbangan yang matang, sehingga karya tersebut tidak hanya dilihat dan dipahami secara luarnya saja tetapi secara isi yang lebih mendalam.

\section{Analisis Data Estetika Gerak Tari Melaju Dengan Mutu}

Berangkat dari teori pada tinjauan pustaka di atas maka dapat dilakukan analisa estetika tari dalam dua hal yaitu Prinsip Estetika Tari dan Prinsip Etika Masyarakat.Gerak sebagai bahasa visual dari sebuah karya tari, gerak tari yang digunakan memiliki kekuatan-kekuatan yang berbeda dari setiap ragamnya. Mencoba memadupadankan beberapa bentuk gerak yang berbeda, dengan karakter yang tidak sama bahkan bertolak 
belakang, maka terwujudlah karya tari Melaju Dengan Mutu ini. Dasar landasan geraknya sangat jelas yaitu gerak tari Bali, gerak tari Melayu, dan gerak tari Jawa.Pemilihan ketiga ciri khas gerak tersebut dilandasi atas perbedaan karakter gerak, dinamika gerak, tempo dan ritme gerak yang tertuang dalam hitungan-hitungan yang ajeg dan konstan.

Ragam gerak tari Melaju Dengan Mutu memiliki 3 bentuk gaya tari yaitu gaya tari Bali, Sumatera Selatan/ Melayu, dan Jawa, dan 1 bentuk gaya yang lebih dinamis yaitu kreasi baru, yang mana dari keempat gaya tari tersebut diolah kembali dan dipilah-pilahkan menjadi 25 ragam gerak. Adapun pembagiannya sebagai berikut:

a. Tari Bali dimulai dari ngumbang, ngelung, ulap-ulap jalan, patah maju tumpang jari tegak mundur.

b. Tari kreasi baru diawali dengan ragam tari semangat, merupakan ragam gerak yang menyimbolkan semangat untuk maju, bersatu dalam setiap keadaan sesuai dengan dinamika kehidupan akademis kampus yang kekinian.

c. Tari Sumatera Selatan /Melayu diawali dengan lenggang, ungkel putar, ungkel, ulap-ulap tunggal kanan kiri, silang tumpang jari,tumpang tali nusuk putar, bedana, salam, putar kanan-kiri, nyongsong, langkah duo. d. Tari Jawa yang menggabungan antara gerak tari Jawa Barat, Jawa Tengah, dan Daerah Istimewa Yogyakarta yaitu kicat kepret, tranjalan kanan kiri, tepuk bahu, jungkat-jungkit, salam penutup, geyol, kicat kembang betangkup, dan ditutupdengan semangat jugag.

Ragam tari yang terpilah-pilah tersebut secara lengkap dibuat diskripsinya. $\mathrm{Hal}$ inidimaksudkan agar pendokumentasian tari tidak hanya dalam bentuk video tetapi juga dalam bentuk tulisan yang lengkap, sehingga dapat dipelajari oleh penikmat tari, pelaku tari, hingga masyarakat yang berada dalam lingkungan akademik dapat melakukan regenerasi dengan cara mengajarkan tarian tersebut melalui workshop dan pelatihan yang akan direncanakan setelah penelitian ini dilaksanakan.

\section{Prinsip Estetika Tari}

Konsep dasar estetika tari terwujud dari bentuk tari itu sendiri.Secara utuh suatu karya tari dipahami dari bentuk yang meliputi tema, alur cerita, gerak, penari, pola lantai, ekspresi wajah, rias, busana, musik iringan, panggung, properti, pencahayaan, setting.Ketika ke 13 komponen terwujud dengan baik maka standar estetika tersebut sudah terwujud dengan baik.Secara utuh karya 
tari Melaju Dengan Mutu memiliki konsep yang dapat dijelaskan dengan baik. Penjelasan yang sangat detail dari aspek tema, alur cerita hingga pencahayaan dapat terdiskripsikan dengan baik. Konsep yang sangat menarik dari karya tari ini adalah dengan menggabungkannya empat gaya tari yang berbeda yaitu tari Bali, tari Melayu, tari Jawa dan gerak modern. Mewujudkan dalam satu kesatuan karya dari keempat gaya tersebut tentu tidak mudah. Jika penata tari tidak secara cermat mengolah gerak-gerak tersebut maka yang terwujud adalah sekedar tempelantempelan gerak yang tidak menarik.

Menentukan empat gaya yang akan digunakan dalam karya tari Melaju Dengan Mutu tersebut melalui tahapan eksplorasi gerak dasar dari masing-masing gaya. Setiap peralihan gaya ditambahkan transisi atau gerak penghubung. Gerak penghubung ini bisa berbentuk gerak tradisi bisa juga dalam bentuk gerak modern.Berangkat dari penentuan konsep gerak tersebut maka dilanjutkan dengan mengolah konsep berikutnya yaitu menentukan tema, alur cerita, penari, pola lantai, ekspresi wajah, rias, busana, musik iringan, panggung, properti, pencahayaan, setting.

Bentuk tari Melaju Dengan Mutu menjadi sangat menarik karena sangat kompleks.Artinya dengan adanya 13 komponen tersebut maka sebuah karya tari dapat dipahami secara utuh dan lengkap.Perwujudan estetika tari itu sendiri juga tercakup secara utuh didalamnya baik dalam bentuk maupun konsep tarinya.

\section{Prinsip Etika Masyarakat}

Prinsip etika masyarkat yang terwujud dalam karya tari Melaju Dengan Mutu adalah hadirnya empat gaya yaitu gaya Bali, gaya Sumatera atau Melayu, dan gaya Jawa serta gaya modern. Pemilihan keempat gaya terseubt tidak serta merta muncul tetapi memiliki dasar yaitu mengkait tentang civitas akademika yang ada di Universitas PGRI Palembang memiliki latar belakang sosial yang beragam. Keberagaman sosial ini diwujudkan dalam tradisi gerak yang kuat namun pada dasarnya memiliki bentuk yang dapat disatukan secara baik. Gaya tradisi lebih dominan dibandingkan gaya modern. Pembagiannya pun gaya tari Sumatera atau Melayu juga lebih mendominasi dibandingkan gaya tari Bali dan Jawa. Hal ini dapat dikaitkan dengan kultur budaya setempat. Budaya setempat akan lebih mendominasi dibandingkan dengan budaya lain, walaupun terdapat beberapa individu yang tidak dapat mengubah budaya dasar. Karya tari Melaju Dengan Mutu, memiliki dasar-dasar konsep yang dapat dipahami oleh penikmat seni tari, mempunyai aturan-aturan yang baku dalam setiap geraknya. Aturan baku dalam gerak ditetapkan sesuai ragam gerak dasar yang diambil kemudian dikembangkan dalam lingkup gerak itu sendiri. Jika gerak dasar yang diambil dari ragam tradisi Jawa maka tradisi baku gerak Jawa akan melekat dengan 
sendirinya. Begitu juga dengan standar ragam

Bali dan Sumantra/Melayu, setiap ragam yang digunakan membawa standar aturan dan tradisi gerak itu sendiri.Batasan-batasan yang mutlak mewakili dari setiap wilayah yang ada.

Prinsip etika yang berlaku pada masyarakat dalam hal ini civitas akademik lingkup Universitas PGRI Palembang menjadi bahan pertimbangan dalam pembuatan sebuah karya tari.hal ini terwujud dengan simbol-simbol gerak yang jelas. Artinyauniversitas memiliki motto yaitu Melaju Dengan Mutu dimana setiap civitas akademika yang terlibat didalamnya untuk turut berperan aktif dalam pelaksanaan Tridharma Perguruan Tinggi, baik pengajaran, penelitian, hingga pengabdian kepada masyarakat.Tarian ini merupakan simbol keragaman budaya dan simbol semangat yang harus dimiliki oleh seluruh civitas akademikanya.Hadirnya tariannya ini mewakili etika masyarakat melalui simbol-simbol gerak berserta komponen yang lainnya.

\section{D.SIMPULAN}

Berdasarkan temuan hasil penelitian tentang Estetika Tari Melaju Dengan Mutu, dapat dikemukakan bahwa pentingnya Estetika sebuah karya tari agar bisa Memperdalam tentang rasa keindahan pencipta tari, penikmat, dan pelaku tarinya. Jika suatu estetika tari sudah terbentuk maka bisa Menyempurnakan rasa keindahan objektif dan Menyempurnakan rasa keindahan subjektif suatu estetika tari yang terbentuk khususnya dalam lingkungan pendidikan dapat memupuk rasa kehalusan manusia untuk mencintai karya seni sebagai alat hiburan dan Memperdalam pengertian keterkaitan wujud berkesenian dengan kehidupan di lingkungan civitas akademika UPGRI Palembang khusunya dan penelitian estetika tari Melaju Dengan Mutu juga disimpulkan bahwa memantapkan kemampuan penilaian kaya seni bisa melalui penelitian bidang seni secara terkait.

Maka dapat disimpulkan bahwa penelitian ini ditemukan empat gaya yang akan digunakan dalam karya tari Melaju Dengan Mutu tersebut melalui tahapan eksplorasi gerak dasar dari masing-masing gaya. Setiap peralihan gaya ditambahkan transisi atau gerak penghubung. Gerak penghubung ini bisa berbentuk gerak tradisi bisa juga dalam bentuk gerak modern.Berangkat dari penentuan konsep gerak tersebut maka dilanjutkan dengan mengolah konsep berikutnya yaitu menentukan tema, alur cerita, penari, pola lantai, ekspresi wajah, rias, busana, musik iringan, panggung, properti, pencahayaan, setting.Bentuk tari Melaju Dengan Mutu menjadi sangat menarik karena terdapat unsurunsur yang menyatu dalam bentuk pertunjukannya sehingga melahirkan estetika tari. 


\section{DAFTAR PUSTAKA}

Hamalik, Oemar. 2004. Perencanaan Pengajaran Berdasarkan Pendekatan Sistem. Jakarta: Bumi Aksara Rohidi, Tjetjep Rohendi. 2011. Metodologi Penelitian Seni. Semarang: Cipta Prima Nusantara.

Sugiyono. 2015. Metode Penelitian Pendidikan. Bandung:Alfabeta. 